\title{
Mackinneyella (Morozova and Lisitsyn, 1996) Fenestrate Genus Described for the First Time from the Devonian Deposits*
}

\author{
Hamed Yarahmadzahi ${ }^{1 \#}$, Andrej Ernst ${ }^{2}$, Zoya Tolokonnikova ${ }^{3}$, Behrooz Sahebzadeh ${ }^{4}$ \\ ${ }^{1}$ Department of Geology, Young Researchers Club, Zahedan Branch, Islamic Azad University, Zahedan, Iran \\ ${ }^{2}$ Institut für Geowissenschaften der Christian-Albrechts-Universität zu Kiel, Kiel, Germany \\ ${ }^{3}$ Faculty of Physical Geography and Geology, Kuzbass State Pedagogical Academy, Novokuznetsk, Russia \\ ${ }^{4}$ Farhangian University, Campus Shahid Motahari, Zahedan, Iran \\ Email: "hamed.yarahmadzahi@gmail.com
}

Received March 6, 2013; revised April 10, 2013; accepted April 21, 2013

Copyright (C) 2013 Hamed Yarahmadzahi et al. This is an open access article distributed under the Creative Commons Attribution License, which permits unrestricted use, distribution, and reproduction in any medium, provided the original work is properly cited.

\begin{abstract}
Mackinneyella fenestrate genus has been reported first time from Lower Permian, Southern Urals (Russia) and then was found Lower Carboniferous to upper permian deposits from Australia, USA, Mongolia, China, Japan, Thailand and Tasmania. This genus is described for the first time from the Devonian deposits of the Kale Sardar section in Tabas area, Central Iran.
\end{abstract}

Keywords: Mackinneyella; Devonian; Kale Sardar Section; Tabas; Central Iran

\section{Introduction}

The Devonian represents an interesting transitional time in the evolution of bryozoans with switchover from Early Palaeozoic bryofaunas typically dominated by trepostomes to Late Palaeozoic bryofaunas in which fenestrates generally dominate [1,2]. These changes were apparently induced by a series of mass extinction events which led to shifts in the taxonomic composition of bryozoan faunas $[3,4]$. Despite their abundance and importance, Devonian bryozoan faunas in many areas remain scarcely investigated. The main reason for this is their complicated internal morphology whose study demands extensive preparation, mainly using oriented thin sections.

The order Fenestellida predominates among Paleozoic bryozoans, probably because of the aromorphic adaptations that arose at the very beginning of its evolution [5]. The differentiation of brood chambers, providing the development of larvae, also facilitated the domination of this group of bryozoans [6,7]. In the evolution of the order there were both long and short lived genera, the latter appeared and developed as ecologically specialized genera. The phenomenon of ecological specialization could also be due to the dominance of this group of bryozoans

*The investigations were carried within the frame of the research project supported by the Islamic Azad University, Zahedan Branch.

\#Corresponding author.
[5]. The above features, which are reflected in the morphology of fenestellid olonies, pose serious difficulties in determining their generic affiliation, as is evidenced by the heterogeneity of the species composition of the genera Fenestella Lonsdale [8], and Polypora McCoy [9]. The problem of heterogeneity of the genera of the order Fenestellida has not lost its topicality, despite a series of papers dealing with different aspects of this issue [1016].

Upper Devonian deposits are widely distributed on the territory of Iran and well dated by conodonts, brachiopods and ammonoidea [17-20]. These sediments also contain various fossils, which have expanded the palaeontological characteristics of formations and are useful for biostratigraphy and palaeobiogeography. One of the most abundant groups in the Upper Devonian sediments of Iran is bryozoans. However, current knowledge about them is very scarce. Several bryozoan species were mentioned by Brice [21] from the Middle-Upper Devonian sediments of the Alborz Mountains: Fistulipora sp., Canutrypa francqana Bassler [22], Eridotrypella? sp., Leptotrypa? sp., Eostenopora sp., Eridotrypa sp., Polypora belgebaschensis Nekhoroshev [23], Rhombopora sp., as well as unidentified trepostomes, fenestrates and rhabdomesines. The species Canutrypa francqana Bassler [22] is known from the Eifelian to Frasnian rocks of France, 
Germany and Poland [22,24-26]. Whereas the species Polypora belgebaschensis Nekhoroshev [23], was reported from the Givetian of Altai Mountains, Kuznetzk Ba$\sin [23,25]$. From the Kuhe Kaftar locality in central Iran were reported Fistulipora spp. (2 species) and Isotrypa sp., Mistiaen [17] were reported. Two species were reported from the Famennian (Geirud Formation) of central Iran: Schulgina mutabilis Troizkaya [27], and Ascopora geirudensis Ernst and Mohammadi [28].

The present paper describes a Mackinneyella Morozova and Lisitsyn [14], from the newly studied Devonian deposits (Shishtu1 Formation) on which is situated in Tabas city ( $\left.33^{\circ} 39^{\prime} 51^{\prime \prime} \mathrm{N}, 57^{\circ} 08^{\prime} 56^{\prime \prime} \mathrm{E}\right)$. Access to the outcrop is via the Tabas-Kharw main road and $22 \mathrm{~km}$ via the minor road of section $2 \mathrm{~km}$ from Niaz village (Figure 1).

\section{Geological Setting}

The Shishtu Formation was first described by Stöcklin [29] in Shotori Mountains. It comprises a sequence of several hundred metres of dark fossiliferous limestones and shales which are transitional from the underlying Bahram Formation of similar lithology and into the overlying Sardar Formation, respectively [30]. The Shishtu Formation is divided into two members, the lower Shishtu 1 and the upper Shishtu 2. The age of the Shishtu 1 member is considered to be Frasnian-Famennian [31,32], whereas Shishtu 2 is attributed to the Tournaisian to early Viséan [33]. In the Shotori Mountains theShishtu 1 member contains a remarkable unit of red brachiopod limestones (about 30 metres) called “Cepha-

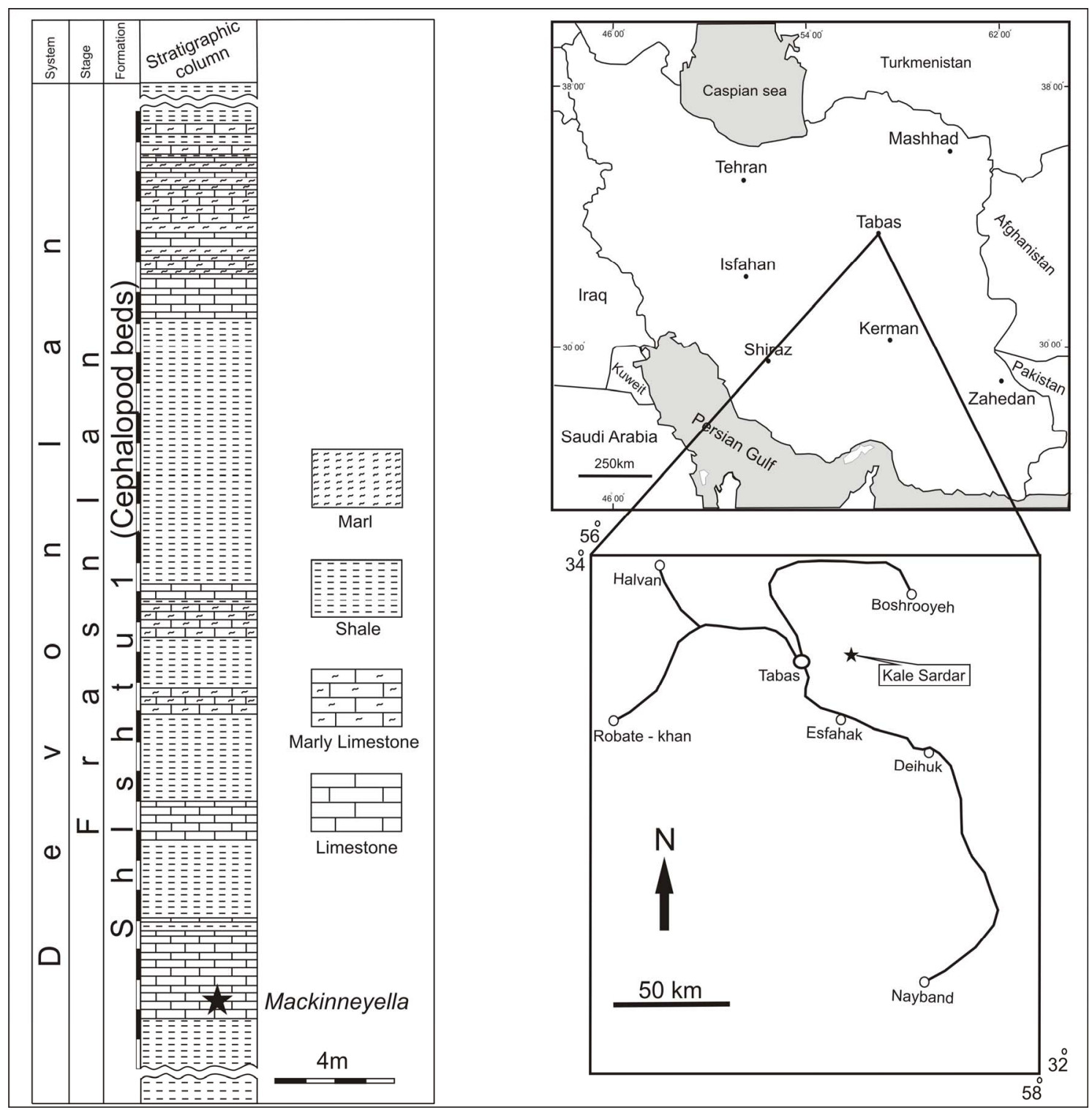

Figure 1. Geographic position of the Kale Sardar locality in the shotori range (eastern Iran) and the stratigraphic succession of the Shishtu Formation with the position of the Mackinneyella horizon. 
lopod Beds" [29]. The age of the "Cephalopod Beds" is diachronous at different localities, and has been established as being the upper Frasnian to lower Famennian by conodonts Wendt [30]. Wendt [18] suggested including the Shishtu Formation in the Bahram Formation, because it does not represent a mappable entity. The bryozoan fauna described in present paper was recovered just below the "Cephalopod Beds" at Niaz section, in a limestone unit rich in corals and stromatoporoids. The "Cephalopod Beds" at the Niaz section have an upper Frasnian age, so the age of the bryozoan-bearing beds is estimated as being middle Frasnian. According to Schröder (pers. comm., 2010) the coral fauna consists mainly of thamnoporid corals, showing a ramose, branching growth, but only few Rugosa belonging mainly to the Phillipsastreidae. The genera Phillipsastrea d'Orbigny [34], Frechastraea Scrutton [35], and Hexagonaria Gürich [36], are represented by fragments of laminar to sub-spherical colonies, which are rather typical for a deeper water environment.

According to Alavi [37], Golonka [38], Aghanabati [39], Wendt [18,30], Palaeozoic sediments in northern Iran represent a fragment of Luarussia (Turan Plate). Fusion of the Iranian Plate (northern Gondwana) and Turan Plate (southern part of Eurasia) occurred during the Mesozoic as a consequence of closure of Palaeothetic Ocean due to subduction [40]. Therefore, the northern edge of Alborz Mountains is regarded as a collision suture zone. The studied territory represented shallow shelf of the continental slope during the Frasnian [18].

\section{Material and Methods}

The preparatory and analytic techniques employed in our study are standard ones for such investigations [41,42]. Quantitative aspects, however, require discussion. The measured morphological parameters utilized in examination of fenestrata bryozoans reported here are similar to those of other studies [41-44].

Bryozoans were investigated in thin sections using a transmitted light microscope. Statistics were summarized with arithmetic mean, sample standard deviation, coefficient of variation, and minimum and maximum value. The studied material includes 25 standard thin sections referring to sample numbers DSH 1-25. The thin sections are housed at the Faculty of Basic Sciences, Islamic Azad University, Zahedan Branch.

\section{Systematic Palaeontology}

By Andrej Ernst

Phylum: Bryozoa Ehrenberg [45]

Class: Stenolaemata Borg [46]

Order: Fenestrata Astrova and Morozova [47]

Suborder: Fenestellina Astrova and Morozova [47]

Family: Acanthocladiidae Ulrich [48]

Genus: Mackinneyella Morozova and Lisitsyn [14]

Type species: Polypora ornamentata Shulga-Nesterenko [49], by subsequent designation by Morozova and Lisitsyn [14]. Lower Permian, Southern Urals (Russia). Plate 1; Table 1.

Material: DSH 1-25
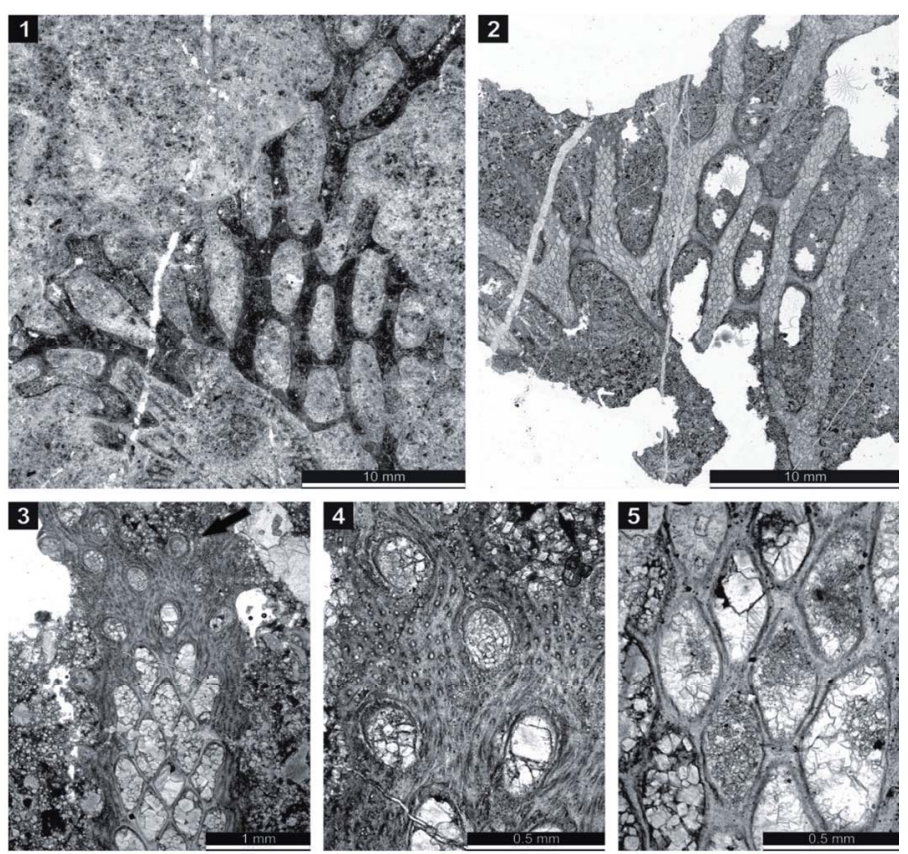

Plate 1. (1)-(5) Mackinneyella (Morozova and Lisitsyn, 1996); (1) General view of the colony; (2) Tangential thin section of the colony; (3), (4) Shallow to middle tangential thin section showing autozooecial apertures and chambers; (5) Middle tangential thin section of the branch showing autozooecial chambers. 
Table 1. Measurements of Mackinneyella Morozova and Lisitsyn [14]. Abbreviations: $\mathrm{N}=$ number of measurements; $\mathrm{X}=$ mean; $\mathrm{SD}=$ standard devition; $\mathrm{CV}=$ coefficient variation; $\mathrm{MIN}=$ minimal value; $\mathrm{MAX}=$ maximal value.

\begin{tabular}{|c|c|c|c|c|c|c|}
\hline Feature & $\mathrm{N}$ & $\mathrm{X}$ & SD & $\mathrm{CV}$ & MIN & MAX \\
\hline Branch width, mm & 10 & 3.2 & 0.805 & 25.06 & 1.1 & 4.0 \\
\hline Dissepiment width, mm & 6 & 1.7 & 0.195 & 11.21 & 1.5 & 2.0 \\
\hline Fenestrule width, mm & 9 & 1.7 & 0.316 & 18.54 & 1.4 & 2.3 \\
\hline Fenestrule length, mm & 7 & 5.0 & 1.252 & 25.07 & 3.2 & 6.8 \\
\hline Distance between branch centres, mm & 9 & 3.1 & 0.341 & 11.17 & 2.6 & 3.7 \\
\hline Distance between dissepiment centres, mm & 4 & 5.0 & 0.858 & 17.08 & 3.8 & 5.6 \\
\hline Aperture width, mm & 20 & 0.16 & 0.012 & 7.73 & 0.13 & 0.18 \\
\hline Aperture spacing along branches, mm & 20 & 0.65 & 0.052 & 8.00 & 0.57 & 0.75 \\
\hline Aperture spacing diagonally, mm & 20 & 0.42 & 0.046 & 11.00 & 0.36 & 0.52 \\
\hline
\end{tabular}

Diagnosis: Reticulated colonies of various shape consisting of broad linear, essentially parallel branches joined by dissepiments; dissepiments narrow, perpendicular or at oblique angle to branches, regularly spaced at large distance; fenestrules elongate oval, sub-rectangular, or irregular in shape; keels and superstructure absent; autozooecia arranged in 5 - 6 rows on branches; chambers slightly elongate, proximally recumbent on budding plate, rhomboidal or rounded hexagonal in mid tangential section, long axis parallel with branch axis; hemisepta and diaphragms absent; granular skeleton present in basal plate and axial wall but locally absent in transverse and lateral autozooecial walls; extrazooecial skeleton laminated, traversed by abundant, moderate-size microstyles.

Remarks: Mackinneyella Morozova and Lisitsyn [14], differs from Polypora M'Coy [9], in having 5 - 6 autozooecial rows on branches instead of 3 - 4 and shape of autozooecia in mid tangential section: rhombic vs.hexagonal.

Stratigraphic and geographic range: Upper DevonianUpper Permian; worldwide.

\section{Conclusion}

In this study, Mackinneyella Morozova and Lisitsyn[14], Fenestrate genus has been reported first time from Lower Permian, Southern Urals (Russia) and then was found Lower Carboniferous to upper permian deposits from Australia, USA, Mongolia, China, Japan, Thailand and Tasmania. This genus is described for the first time from the Devonian deposits of the Kale Sardar section in Tabas area, Central Iran.

\section{REFERENCES}

[1] R. J. Cuffey and F. K. McKinney, "Devonian Bryozoa,"
Special Papers in Palaeontology, 1979, pp. 307-311.

[2] F. P. Bigey, "Devonian, a Transitional Period for Bryozoans,” Terra Cognita, 1985, p. 210.

[3] A. S. Horowitz and J. F. Pachut, "Specific, Generic, and Familial Diversity of Devonian Bryozoans," Journal of Paleontology, Vol. 67, No. 1, 1993, pp. 42-52.

[4] A. S. Horowitz, J. F. Pachut and R. L. Anstey, "Devonian bryozoan diversity, extinctions and originations," Journal of Paleontology, Vol. 70, No. 3, 1996, pp. 373-380.

[5] R. V. Gorjunova, A. V. Markov and E. B. Naimark, "Evolyutsiya i Biogeografiya Paleozoiskikh Mshanok (Evolution and Biogeography of Paleozoic Bryozoans)," GEOS, Moscow, 2004.

[6] R. Tavener Smith, "Ovicells in Fenestrate Cryptostomes of Viséan Age," Journal of Paleontology, Vol. 40, No. 1, 1966, pp. 190-198.

[7] I. P. Morozova, "Bryozoans of the Order Fenestellida (Morphology, System, Historical Development) (in Russian)," Trudy Paleontologischeskogo Instituta, Vol. 277, 1-176.

[8] W. Lonsdale, “Corals," In: R.I. Murchison, Ed., The Silurian System, Part 2. Organic Remains, 1839, pp. 675694.

[9] F. M'Coy, "A Synopsis of the Characters of the Carboniferous Limestone Fossils of the Ireland," Dublin University Press, Dublin, 1844, pp. 1-207. doi:10.5962/bhl.title.11559

[10] H. Termier and G. Termier, "Bryozoaires du Paléozoïque supérieur de l'Afghanistan," Documents des Laboratoires de Géologie de Lyon, No. 47, 1971, pp. 1-52.

[11] I. P. Morozova, "Revision of the genus Fenestella," Journal of Paleontology, Vol. 8, No. , 1974, pp. 167-180

[12] P. N. Wyse Jackson, "New Fenestrate Bryozoa from the Lower Carboniferous of County Fermanagh,” Irish Journal of Earth Sciences, Vol. 9, No. 1, 1988, pp. 197-208.

[13] E. M. Snyder, "Revised Taxonomic Procedures and Paleo Ecological Applications for Some North American Missis_Sippian Fenestellidae and Polyporidae (Bryo- 
zoa)," Palaeontographica Americana, Vol. 57, No. 1, 1991, pp. 1-275.

[14] I. P. Morozova and D. V. Lisitsyn, "Revizia Roda Polypora M’Coy 1844 (Revision of the Genus Polypora M’Coy 1844),” Paleontologicheskij Zhurnal, Vol. 4, No. 1, 1996, pp. 38-47.

[15] S. J. Hageman and F. K. McKinney, "Discrimination of Fenestrate Bryozoan Genera in Morphospace,” Palaeontol Electron, Vol. 13, No. 2, 2010, pp. 1-42.

[16] R. V. Gorjunova and O. B. Weiss, "A New Genus Acupipora gen. nov. from the Upper Carboniferous of the East European Platform and Problem of Classification of Bryozoans of the Order Fenestellida," Paleontological Journal, Vol. 46, No. 1, 2012, pp. 16-28.

[17] B. Mistiaen, H. Gholamalian, R. Gourvennec, Y. Plusquellec, F. Bigey, D. Brice, M. Feist, R. Feist, M. Ghobadipour, M. Kebriaee, B. Milhau, J.-P. Nicollin, J.-C. Rohart, D. Vachard and M. Yazdi, "Preliminary data on the Upper Devonian (Frasnian, Famennian) and Permian fauna and flora from the Chariseh area (Esfahan Province, Central Iran),” Annales de la Société Géologique du Nord, 2e Série, 2000, pp. 93-102.

[18] J. Wendt, B. Kaufmann, Z. Belka, N. Farsan and A. K. Bavandpur, "Devonian/Lower Carboniferous Stratigraphy, Facies Patterns and Palaeogeography of Iran, Part 2. North and Central Iran,” Acta Geologica Polonica, 2005, pp. 31-97.

[19] A. R. Ashouri, "Middle Devonian-Early Carboniferous conodont faunas from the Khoshyeilagh Formation, Alborz Mountains, North Iran,” Journal of Sciences, Vol. 17, No. 1, 2006, pp. 53-65.

[20] V. Hairapetian and D. Korn, "Phylogenetic analysis of the family Beloceratidae (Ammonoidea; Late Devonian) and a New Beloceras Species from Eastern Iran,” Bulletin of Geosciences, 2011, pp. 675-682.

[21] D. Brice, J. Jenny, G. Stamfli and F. Bigey, "Le Devonien de l'Elbourz Oriental: Stratigraphie, Paléontologie (Brachiopodes et Bryozoaires), Paléogeographie,” Rivista Italiana di Paleontogia e Stratigrafia, 1978, pp. 1-56.

[22] R. S. Bassler, "Taxonomic Notes on Genera of Fossil and Recent Bryozoa," Journal of the Washington Academy of Sciences, Vol. 42, No. 1, 1952, pp. 381-385.

[23] V. P. Nekhoroshev, "Devonian Bryozoa of the Altai," Trudy Paleontologischeskogo Instituta Akademiya Nauk SSSR, 1948, pp. 1-172.

[24] F. P. Bigey, "Bryozoaires du Givétien et du Frasnien de Ferques (Boulonnais, France),” In: D. Brice, Ed., Le Devonien de Ferques, Bas-Boulonnais (N. France); Paléontologie, Sédimentologie, Stratigraphie, Tectonique, Biostratigraphie du Paléozoïque, 1988, pp. 297-323.

[25] I. P. Morozova, O. B. Weis and G. Racki, "Emergence and Extinction of the Givetian to Frasnian Bryozoan Faunas in the Kostomloty Facies Zone, Holy Cross Mountains, Poland," Acta Palaeontologica Polonica, Vol. 47, No. 2, 2002, pp. 307-317.

[26] A. Ernst, "Non-Fenestrate Bryozoans from the Middle Devonian of the Eifel (Western Rhenish Massif, Germany)," Neues Jahrbuch für Geologie und Paläontologie,
Abhandlungen, Vol. 250, No. 3, 2008, pp. 313-379. doi:10.1127/0077-7749/2008/0250-0313

[27] T. D. Troizkaya, "Main Features of the Development of Bryozoans in Central Kazakhstan at the Boundary between the Devonian and the Carboniferous," Paleontologicheskij Zhurnal, Vol. 3, No. 1, 1975, pp. 54-69.

[28] A. Ernst and M. Mohammadi, "Stenolaemate bryozoans from the Geirud Formation (Upper Devonian/Lower Carboniferous) of Central Alborz (Iran),” Paläontologische Zeitschrift, Vol. 83, No. 1, 2009, pp. 439-447.

[29] J. Stöcklin, J. Eftekhar-nezad and A. Hushmand-zadeh, "Geology of the shotori range (Tabas area, East Iran)," Geological Survey of Iran, 1965, pp. 1-69.

[30] J. Wendt, J. Hayer and A. Karimi, "Bavandpour, Stratigraphy and Depositional Environment of Devonian Sediments in Northeast and East-Central Iran,” Neues Jahrbuch fur Geologie und Palaontologie Abhandlungen, Vol. 206, No. 1, 1997, pp. 277-322.

[31] K. Weddige, "Externally controlled Late Paleozoic Events of the Iran Plate," Neues Jahrbuch für Geologie und Paläontologie, Abhandlungen, Vol. 168, No. 1, 1984, pp. 278-286.

[32] M. Yazdi, "Late-Devonian-Carboniferous Conodonts from Eastern Iran,” Rivista Italiana di Paleontologica e Stratigrafia, Vol. 105, No. 1, 1999,pp. 167-200.

[33] J. Stöcklin, "Iran Central, Septentrional et Oriental. En Collaboration Avec les Géologues du Service Géologique de l'Iran,” Lexique Stratigraphique International, Vol. 3 , No. 1, 1972, pp. 1-376.

[34] A. d'Orbigny, "Description de Quelques Genres Nouveaux de Mollusques Bryozoaires," Revue et Magazine de Zoologie Pure et Appliquée, Vol. 2, No. 1, 1849, pp. 499504.

[35] C. T. Scrutton, "Colonial Phillipsastraeidae from the Devonian of South-East Devon, England,” Bulletin of the British Museum (Natural History), Vol. 15, No. 5, 1968 , pp. 183-281.

[36] G. Gürich, "Das Paläozoicum im Polnischen Mittelgebirge,” Verhandlugen der Russischen-Kaiserlichen Mineralogischen Gesellschaft zu St-Petersburg, Vol. 2, No. 32, 1896, pp. 1-539.

[37] M. Alavi, "Tectonostratigraphic Synthesis and Structural Style of the Alborz Mountain System in Northern Iran," Journal of Geodynamics, Vol. 21, No. 1, 1996, pp.1-33. doi:10.1016/0264-3707(95)00009-7

[38] J. Golonka, "Cambrian-Neogene Plate Tectonic Maps,” Wydawnictwa Uniwersytetu Jagiellonskiego, Kraków, 2000, pp. 1-125.

[39] A. Aghanabati, “Geology of Iran,” Geological Survey of Iran, Tehran, 2004, p. 586.

[40] J. Golonka, "Plate-Tectonic Maps of the Phanerozoic,” In: W. Kiessling, E. Flu"gel and J. Golonka, Eds., Phanerozoic Reef Patterns, SEPM Special Publication, 2002, pp. 21-75.

[41] R. J. Cuffey, "Bryozoan Tabulipora Carbonaria in Wreford Megacyclothem (Lower Permian) of Kansas," University of Kansas, Wichita, 1967, pp. 1-96. 
[42] G. B. Newton, "Rhabdomesid Bryozoans of the Wreford Megacyclothem (Wolfcampian, Permian) of Nebraska, Kansas, and Oklahoma," University of Kansas Paleontological Institute, Lawrence, 1971, pp. 1-71.

[43] A. S. Horowitz, "The Ectoproct (Bryozoan) Genus Actinotrypa Ulrich,” Journal of Paleontology, Vol. 42, No. 2, 1968, pp. 356-373.

[44] B. Foerster, "Skeletal Morphology, Variability, and Ecology of the Bryozoan Species Crisia Eburnca in the Modern Reefs of Bermuda,” Master's Thesis, Pennsylvania State University, University Park, 1970, p. 212.

[45] C. G. Ehrenberg, "Symbolae Physicae Seu Icones et Descriptiones Corporum Naturalium Novorum aut Minus Cognitorum, Quae ex Itineribus per Libyam, Aegyptum, Nubiam, Dongalaam, Syriam, Arabiam Ridiret Pars Zoologica," Animalia Erertebrata exclusis insectis, Vol. 4, 1831, pp. 1-10.
[46] F. Borg, "Studies on Recent Cyclostomatous Bryozoa," Zoologiska Bidlag Fran Uppsala, Vol. 10, No. 1, 1926, pp. 181-507.

[47] G. G. Astrova and I. P. Morozova, "K Sistematike Mshanok Otryada Cryptostomata [About Systematics of the Order Cryptostomata]," Doklady Akademii Nauk SSSR, Moscow, 1956, pp. 661-664.

[48] E. O. Ulrich, “Paleozoic Bryozoa: III,” Geological Survey, Champaign, 1890, pp. 283-688.

[49] M. I. Shulga-Nesterenko, "Nizhnepermski Mshanki Urala [Lower Permian Bryozoa of the Urals],” Paleontologiya SSSR, Trudy Paleontologicheskogo Instituta, Moscow, 1941, pp. 1-276. 